J. Product. \& Dev., 23(1): 147-156(2018)

\title{
STUDIES ON THE POSSIBILITIES TO USE AGRICULTURAL AND FOOD WASTES TO PRODUCE ETHANOL ALCOHOL. 1-FACTORS AFFECTING THE ETHANOL PRODUCTION FROM SUGAR BEET MOLASSES
}

\author{
Awatif L. Mohamed; A. EL-Makhzangy ;M. Suleiman and A.EL-Shawaf \\ Food Technology, Faculty of Technology \&Development, Zagazig University, Egypt.
}

\section{ABSTRACT}

The conditions production of bioethanol from beet molasses was investigated by Saccharomyces cerevisiae Meyen ex E.C. Hansen (1883). Data showed that 2\% inoculums size was the best size of all tested for molasses media size. Where the alcohol production was 4.6 $\mathrm{ml} / 100$ media with economic coefficient $53.7 \%$ and yield coefficient 46.1\%. Also, incubation periods were tested from 2 to 14 days. Maximum alcohol production was noticed at the sixth day of fermentation, it was $4.71 \% \mathrm{ml} / 100 \mathrm{ml}$ medium.

The same observation was found with the economic and yield coefficient, it was $53.7 \%$ and $46.1 \%$ respectively. Results showed at $30^{\circ} \mathrm{C}$ incubation temperature the yeast of Saccharomyces cerevisiae produced high value of ethanol production. $4.61 \mathrm{ml} / 100 \mathrm{ml}$ medium with high value of economic coefficient $53.7 \%$ and $46.1 \%$ of yield coefficient. While PH 5 was the optimal value for ethanol production from molasses, where alcohol production was $4.61 \%$, economic coefficient and yield coefficient were $53.7 \%$ and $46.1 \%$, respectively. Increasing the $\mathrm{PH}$ value up to 5.5 did not increase the ethanol production. but ethanol production was recorded decrease value.

Data showed that at $20{ }^{\circ} \mathrm{C}$ incubation temperature and $14.0 \%$ initial, sugar the ethanol production was $5.16 \%$ with $40 \%$ economic coefficient, while at $30^{\circ} \mathrm{C}$ temperature incubation the maximum ethanol production was $6.3 \%$ with economic coefficient $49.0 \%$ where the initial sugar was $14.0 \%$ in media.

Conclusively, food and Agricultural wastes can be used for ethanol production using Saccharomyces cerevisiae under anaerobic condition. Maximum Yield of ethyl was $6.3 \%$ with economic coefficient $49.9 \%$

Key words: Agricultural \& Food Wastes, ethanol alcohol, ethanol production, sugar beet molasses. 


\section{INTRODUCTION:}

Food wastes are the final wastes of the industrial processes the of crops vegetables and fruits that cannot be retained to processed foods and can not be used for other purposes, and the costs paid to gather them are higher than their economic value (Nakshoo et al., 2013). Therefore discarded as waste. Since ours is an agricultural country where agricultural wastes are dumped in large volumes, ethanol derived from biomass may serve as a viable option.

So, the aim of the present study were carried out to study the possibilities to use agricultural and food wastes to produce ethanol alcohol.

\section{MATERIALS AND METHODS}

Saccharomyces cerevisiae: It was obtained in the form of pellets from Microbiological Resource Center, Cairo "MERCEN", Faculty of Agriculture, Ain-Shams University, Egypt.

\section{Food factories wastes:}

Sugar-beet molasses: It was obtained from Egyptian sugar and Distillery company Belgass Factory, EL- Dakahlia Goveorate.

Potato dextrose agar (PDA): Potato dextrose agar medium was prepared as following : $200 \mathrm{gm}$. Potato tuber was boiled in water and then filtered 20 gm Dextrose and $17 \mathrm{gm}$ Agar-agar were added to $200 \mathrm{ml}$ of the above filtrate. The final volume of the medium was adjusted to $1000 \mathrm{ml}$. by adding tap water. $\mathrm{pH}$ was adjusted at 6.5 .

Yeast mold broth (BD 271120 ) as manufacturer, s instructions :Dextrose $10.0 \mathrm{~g}$; Peptones $5.0 \mathrm{~g}$; yeast extract $3.0 \mathrm{~g}$; malt extract $3.0 \mathrm{~g}$ Agar $15.0 \mathrm{~g}$ and Distilled water 1.0 L.

Chemical analysis: Total sugars, reducing and non-reducing sugars, were determined as A.O.A.C. (2005).

Preparation of inoculums: Yeast appeared on (P.D.A) Potato dextrose agar media scrapped off using $5 \mathrm{ml}$ sterilized distilled water, and dispensed in a flask containing $30 \mathrm{ml}$. sterilized distilled water. colony forming unit (C F U) were counted by using plate count. 
Fermentation: The molasses was dissolved in distilled water to give different sugar concentration $(8,10,12$, and $14 \%)$ and then the $\mathrm{pH}$ value was adjusted to (4.0, 4.5, 5.0, and 5.5 ). Dispensing $200 \mathrm{ml}$ fermenting solution in every one liter Erlenmeyer flask were added. Sufficient sterilization by autoclaving at 1.5 atmosphere pressure for $20 \mathrm{~min}$. The inoculation was carried out using suitable size of yeast suspension for each flask $(200 \mathrm{ml}$.$) the fermenting flasks were incubated at different$ temperatures for different time to indicate the optimal temperature and the optimal time for ethanol production.

Determination of Ethyl alcohol content: According to Itelima et al., (2013) using pyknometer method for determining the specific gravity of the distillate as follows: take a clean and dry pyknometer and weigh it empty along with the stopper at $20^{\circ} \mathrm{c}(\mathrm{W})$. fill it with liquor sample to the brim and insert the stopper gently wipe the liquid that spills out using water absorbing filter paper and weigh at $20^{\circ} \mathrm{c}\left(\mathrm{W}_{1}\right)$. Next remove the liquor sample and wash it with distilled water. Fill the pyknometer with distilled water in the same manner as described above and take the weight $\left(\mathrm{W}_{2}\right)$.

$$
\text { Sp.Gravity }=\mathrm{W}_{1}-\mathrm{W} / \mathrm{W}_{2}-\mathrm{W}
$$

Find out the corresponding alcohol percent by volume from the standard curve prepared previously using absolute Ethanol and distilled water.

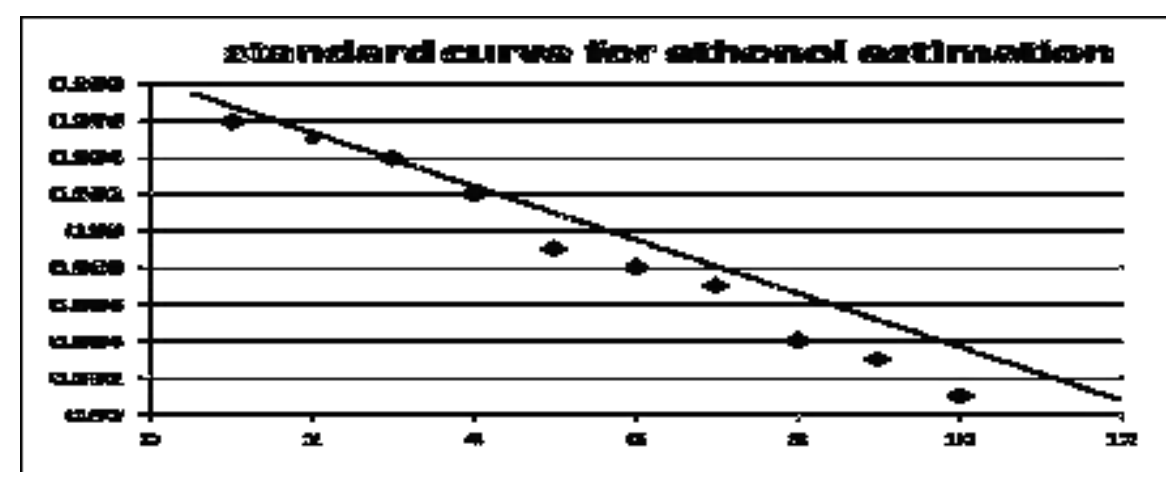

\section{RESULTS AND DISCUSSION}

From the data in Table (1), it could be observed that $2 \%$ inoculum size was the best size of all tested size ; where the alcohol production was $4.6 \mathrm{ml} / 100 \mathrm{ml}$ media with economic coefficient $53.7 \%$ and yield coefficient $46.1 \%$. When use $2.5,3$ and $3.5 \%$ inoculum size the percentage of ethanol production were decreased till $4.1 \%$ and the economic coefficient also decreased to $47 \%$. 
Table (1): Effect of inoculum size on ethanol production efficiency after 4 days of fermentation from molasses media using Saccharomyces cerevisiae.*

\begin{tabular}{|c|c|c|c|c|c|c|}
\hline $\begin{array}{c}\text { Inoculums } \\
\text { size } \\
\mathbf{\%}\end{array}$ & $\begin{array}{c}\text { Initial } \\
\text { sugars } \\
\mathbf{\%}\end{array}$ & $\begin{array}{c}\text { Residual } \\
\text { sugars } \\
\mathbf{\%}\end{array}$ & $\begin{array}{c}\text { Consumed } \\
\text { sugars } \\
\mathbf{\%}\end{array}$ & $\begin{array}{c}\text { Alcohol } \\
\text { production } \\
\mathbf{\%}\end{array}$ & $\begin{array}{c}\text { Economic } \\
\text { coefficient } \\
\boldsymbol{\%}\end{array}$ & $\begin{array}{c}\text { Yield } \\
\text { coefficient } \\
\boldsymbol{\%}\end{array}$ \\
\hline $\mathbf{1 . 0}$ & 10.0 & 1.98 & 8.02 & 4.60 & 50.6 & 40.6 \\
\hline $\mathbf{1 . 5}$ & 10.0 & 1.71 & 8.29 & 4.20 & 50.6 & 42.0 \\
\hline $\mathbf{2 . 0}$ & 10.0 & 1.42 & 8.58 & 4.61 & 53.7 & 46.1 \\
\hline $\mathbf{2 . 5}$ & 10.0 & 1.40 & 8.60 & 4.10 & 47.0 & 41.0 \\
\hline $\mathbf{3 . 0}$ & 10.0 & 1.37 & 8.63 & 4.10 & 47.0 & 41.0 \\
\hline $\mathbf{3 . 5}$ & 10.0 & 1.37 & 8.63 & 4.10 & 47.0 & 41.0 \\
\hline
\end{tabular}

*at $\mathrm{pH}$, and incubation temperature $30{ }^{\circ} \mathrm{C}$.

Generally, above or under this size of inoculums the economic and yield coefficient were decreased as the large number of yeast in the anaerobic medium compete to use sugar available is the production on non-alcohol materials . On the contrary, small number of yeast (low inoculum size) consume the sugar available in there reproduction and build themselves (Nakshoo et al., 2013). Singh et al. (2014) who reported that 3\% yeast concentration was the optimal for completion of fermentation and the maximum ethanol production was completely achieved in 7 days. Also, Turhan et al., (2008) reported that maximum ethanol concentration, ethanol productivity and ethanol yield were obtained with an initial inoculum of $3 \%$ when carob extract as a substrate by using $S$. cerevisiae.

Data in this Table (2) shows that incubation periods were tested at $2,4,6,8,10,12$, and 14 days. Maximum alcohol production was noticed at the sixth day of fermentation, it was $4.71 \%$ ( $\mathrm{ml} / 100 \mathrm{ml}$ medium). The same observation were found with the economic and yield coefficient; it were 53.7 and $46.1 \%$; respectively. Long period of incubation after the sixth days showed gradually decreased in both alcohol, economic and yield coefficient. There may be attributed to consumed the produced alcohol as a carbon source to feed the yeast. On the other hand, the fermentation periods before the sixth days 2 and 4 days showed decrement amounts is ethanol production and economic coefficient this may be to the need of yeast to achieve the necessary enzyme for saccharification (Rani et al., 2010).

Data in Table (3) showed at $30^{\circ} \mathrm{C}$ incubation temperature the yeast of Saccharomyces cerevisiae produced a high value of ethanol production 4.60 $\mathrm{ml}$ alcohol per $100 \mathrm{ml}$ medium with a high value of economic coefficient $53.7 \%$ and $46.1 \%$ of yield coefficient. 
Table (2) : Effect of Incubation periods (days) on ethanol production from sugar beet molasses media using Saccharomyces cerevisiae.*

\begin{tabular}{|c|c|c|c|c|c|c|}
\hline $\begin{array}{c}\text { Incubation } \\
\text { period } \\
\text { (day) }\end{array}$ & $\begin{array}{c}\text { Initial } \\
\text { sugars } \\
\mathbf{\%}\end{array}$ & $\begin{array}{c}\text { Residual } \\
\text { sugars } \\
\mathbf{\%}\end{array}$ & $\begin{array}{c}\text { Consumed } \\
\text { sugars } \\
\mathbf{\%}\end{array}$ & $\begin{array}{c}\text { Alcohol } \\
\text { production } \\
\mathbf{\%}\end{array}$ & $\begin{array}{c}\text { Economic } \\
\text { coefficient } \\
\mathbf{\%}\end{array}$ & $\begin{array}{c}\text { Yield } \\
\text { coefficient } \\
\mathbf{\%}\end{array}$ \\
\hline $\mathbf{2}$ & 10.0 & 1.53 & 8.47 & 4.10 & 50.0 & 41.0 \\
\hline $\mathbf{4}$ & 10.0 & 1.42 & 8.58 & 4.61 & 48.4 & 41.6 \\
\hline $\mathbf{6}$ & 10.0 & 1.39 & 8.61 & 4.71 & 53.7 & 46.1 \\
\hline $\mathbf{8}$ & 10.0 & 1.10 & 8.90 & 4.31 & 48.4 & 43.1 \\
\hline $\mathbf{1 0}$ & 10.0 & 0.92 & 9.08 & 4.40 & 48.4 & 44.0 \\
\hline $\mathbf{1 2}$ & 10.0 & 0.91 & 9.09 & 4.35 & 47.8 & 43.5 \\
\hline $\mathbf{1 4}$ & 10.0 & 0.91 & 9.09 & 4.33 & 47.8 & 43.5 \\
\hline
\end{tabular}

* at $\mathrm{pH} 5$, incubation temperature $30{ }^{\circ} \mathrm{C}$ and inoculum volume was $2 \%$.

Table (3) : Effect of incubation temperature $\left({ }^{\circ} \mathrm{C}\right)$ on ethanol production from molasses media using Saccharomyces Cerevisiae. *

\begin{tabular}{|c|c|c|c|c|c|c|}
\hline $\begin{array}{c}\text { Incubation } \\
\text { temperature } \\
{ }^{\circ} \mathbf{C}\end{array}$ & $\begin{array}{c}\text { Initial } \\
\text { sugars } \\
\mathbf{\%}\end{array}$ & $\begin{array}{c}\text { Residual } \\
\text { sugars } \\
\mathbf{\%}\end{array}$ & $\begin{array}{c}\text { Consumed } \\
\text { sugars } \\
\mathbf{\%}\end{array}$ & $\begin{array}{c}\text { Alcohol } \\
\text { production } \\
\mathbf{\%}\end{array}$ & $\begin{array}{c}\text { Economic } \\
\text { coefficient } \\
\mathbf{\%}\end{array}$ & $\begin{array}{c}\text { Yield } \\
\text { coefficient } \\
\mathbf{\%}\end{array}$ \\
\hline $\mathbf{2 0}$ & 10.0 & 1.74 & 8.53 & 4.03 & 47.2 & 40.3 \\
\hline $\mathbf{2 5}$ & 10.0 & 1.52 & 8.48 & 4.13 & 48.7 & 41.3 \\
\hline $\mathbf{3 0}$ & 10.0 & 1.39 & 8.61 & 4.61 & 53.7 & 46.1 \\
\hline $\mathbf{3 5}$ & 10.0 & 0.73 & 9.72 & 4.52 & 48.7 & 45.2 \\
\hline
\end{tabular}

*at $\mathrm{pH} 5$, incubation period 6 days and inoculum volume $2 \%$.

On the other hands, the incubation temperature under this value 20, 25 or above at $35^{\circ} \mathrm{C}$ showed a decrease values of both ethanol production, economic and yield coefficient.

As generally, most references showed that in un aerated fermentation; maximum yeast metabolic activity takes place at about $30^{\circ} \mathrm{C}$. whereas the growth rate in aerated culture is highest at $35{ }^{\circ} \mathrm{C}$ and greatly affected by increasing of temperature until $42{ }^{\circ} \mathrm{C}$. (Singh et al., 2014). Which stated that incubation temperature is an important factors that effect the fermentation process and product formation. It commonly believed that 20 $35^{\circ} \mathrm{C}$ is the ideal range for fermentation.

Data in Table (4) clear that $\mathrm{pH} 5$ was the optimal value of $\mathrm{pH}$, where alcohol production was $4.60 \%$ while economic coefficient and yield coefficient were 53.7 and $46.1 \%$; respectively. From this table also we can notice the decrease in alcohol production; economic coefficient and yield coefficient in case of increase or decrease above or under the optimum $\mathrm{pH}$ value. These results were in agreement with result at obtained by Nakshoo 
Table (4): Effect of different $\mathrm{pH}$ values on ethanol production from molasses media using Saccharomyces Cerevisiae*

\begin{tabular}{|c|c|c|c|c|c|c|}
\hline $\begin{array}{c}\text { pH } \\
\text { value }\end{array}$ & $\begin{array}{c}\text { Initial } \\
\text { sugars } \\
\mathbf{\%}\end{array}$ & $\begin{array}{c}\text { Residual } \\
\text { sugars } \\
\mathbf{\%}\end{array}$ & $\begin{array}{c}\text { Consumed } \\
\text { sugars } \\
\mathbf{\%}\end{array}$ & $\begin{array}{c}\text { Alcohol } \\
\text { production } \\
\mathbf{\%}\end{array}$ & $\begin{array}{c}\text { Economic } \\
\text { coefficient } \\
\mathbf{\%}\end{array}$ & $\begin{array}{c}\text { Yield } \\
\text { coefficient } \\
\mathbf{\%}\end{array}$ \\
\hline $\mathbf{4 . 0}$ & 10.0 & 1.67 & 8.33 & 3.91 & 46.9 & 39.1 \\
\hline $\mathbf{4 . 5}$ & 10.0 & 1.52 & 8.48 & 3.98 & 46.9 & 39.8 \\
\hline $\mathbf{5 . 0}$ & 10.0 & 1.39 & 8.61 & 4.61 & 53.7 & 46.1 \\
\hline $\mathbf{5 . 5}$ & 10.0 & 1.22 & 8.78 & 4.12 & 46.9 & 41.2 \\
\hline $\mathbf{6 . 0}$ & 10.0 & 1.67 & 8.33 & 3.90 & 46.8 & 39.5 \\
\hline $\mathbf{6 . 5}$ & 10.0 & 1.92 & 8.08 & 3.79 & 46.8 & 37.9 \\
\hline
\end{tabular}

*Under optimum conditions tested before .

et al., (2013) who observed that $\mathrm{pH} 5$ and temperature $30^{\circ} \mathrm{C}$ were the optimum conditions for production of bio ethanol from sugar refining molasses by the local isolate of Saccharomyces cerevisiae.

Data recorded in Table (5) show that at the end of $3^{\text {ed }}$ day of incubation period; ethanol production were $2.88,3.76,4.31,5.86$ and $6.3 \%$ with economic coefficient 48.0, 47.0, 45.9, 48.9 and $47.4 \%$ when the initial sugars were 6,8 , 10,12 , and $14 \%$; respectively. Generally from this Table, it could be concluded

Table (5): Interaction between initial sugar concentrations and incubation period on ethanol production from molasses media using Saccharomyces cerevisiae .

\begin{tabular}{|c|c|c|c|c|c|c|}
\hline $\begin{array}{c}\text { Incubation } \\
\text { period } \\
\text { (days) }\end{array}$ & $\begin{array}{c}\text { Initial } \\
\text { sugars } \\
\mathbf{\%}\end{array}$ & $\begin{array}{c}\text { Residual } \\
\text { sugars } \\
\mathbf{\%}\end{array}$ & $\begin{array}{c}\text { Consumed } \\
\text { sugars } \\
\mathbf{\%}\end{array}$ & $\begin{array}{c}\text { Alcohol } \\
\text { production } \\
\mathbf{\%}\end{array}$ & $\begin{array}{c}\text { Economic } \\
\text { coefficient } \\
\mathbf{\%}\end{array}$ & $\begin{array}{c}\text { Yield } \\
\text { coefficient } \\
\text { \% }\end{array}$ \\
\hline \multirow{2}{*}{$\mathbf{1}^{\text {St }}$} & 6 & 1.47 & 4.53 & 2.03 & 44.8 & 33.8 \\
& 8 & 1.72 & 6.28 & 2.82 & 44.9 & 35.2 \\
& 10 & 2.82 & 7.13 & 3.20 & 44.8 & 32.0 \\
& 12 & 2.83 & 9.17 & 4.12 & 44.9 & 34.3 \\
& 14 & 3.73 & 10.63 & 4.78 & 44.9 & 34.1 \\
\hline \multirow{2}{*}{$\mathbf{2}^{\text {nd }}$} & 6 & 0.04 & 5.96 & 2.80 & 46.9 & 46.6 \\
& 8 & 0.08 & 7.72 & 3.70 & 47.9 & 46.2 \\
& 10 & 1.39 & 8.61 & 4.31 & 44.0 & 43.1 \\
& 12 & 0.28 & 11.72 & 5.86 & 50.0 & 48.8 \\
& 14 & 1.13 & 12.87 & 6.30 & 48.9 & 45.0 \\
\hline \multirow{3}{*}{$3 e d$} & 6 & 0.00 & 6.00 & 2.88 & 46.9 & 46.6 \\
& 8 & 0.00 & 8.00 & 3.76 & 47.9 & 46.2 \\
& 10 & 0.62 & 9.38 & 4.31 & 44.0 & 43.1 \\
& 12 & 0.03 & 11.97 & 5.86 & 50.0 & 48.8 \\
& 14 & 0.64 & 13.36 & 6.30 & 48.9 & 45.0 \\
\hline
\end{tabular}


that; at the end of $2^{\text {nd }}$ day; maximum ethanol production was $6.3 \%$ at $14.0 \%$ initial sugars. The percentage of ethanol production didn't increase with increasing the incubation periods these results were agreeable with findings of Kandar and Gupata (2012) and Nakshoo et al., (2013).

From Table (6) we can notice that; at $\mathrm{P}^{\mathrm{H}} 4.5$ the maximum alcohol production was $5.31 \%$ at $14.0 \%$ initial sugar used in the media with economic coefficient $43.9 \%$. While, at 6.0, 8.0, 10.0, and $12.0 \%$ Initial sugar used the ethanol production were 2.71, 3.13, 3.85 and 4.57\%; respectively. Whereas in case of $\mathrm{pH}$ at 5.0 the ethanol production was $6.3 \%$ when the initial sugar was $14.0 \%$. Meanwhile; the ethanol production were $2.80,3.75,4.13$, and $5.86 \%$ with economic coefficient 46.9, 47.9, 44.0 and $50 \%$ when initial sugars were $6,8,10$ and $12 \%$; respectively. Increasing the $\mathrm{pH}$ values up to 5.5 didn't increase the ethanol production but ethanol production were recorded a decrease value; $2.59,2.98,3.83,4.46$ and $5.1 \%$ when the initial sugars were $6.0,8.0,10.0,12.0$ and $14.0 \%$; respectively Nakshoo et al., (2013).

Table (6): Interaction between different $\mathrm{pH}$ values and initial sugar concentrate on alcohol production from molasses media using Saccharomyces cerevisiae under optimum conditions.

\begin{tabular}{|c|c|c|c|c|c|c|}
\hline $\begin{array}{c}\mathbf{p H} \\
\text { values }\end{array}$ & $\begin{array}{c}\text { Initial } \\
\text { sugars } \\
\mathbf{\%}\end{array}$ & $\begin{array}{c}\text { Residual } \\
\text { sugars } \\
\mathbf{\%}\end{array}$ & $\begin{array}{c}\text { Consumed } \\
\text { sugars } \\
\mathbf{\%}\end{array}$ & $\begin{array}{c}\text { Alcohol } \\
\text { production } \\
\mathbf{\%}\end{array}$ & $\begin{array}{c}\text { Economic } \\
\text { coefficient } \\
\mathbf{\%}\end{array}$ & $\begin{array}{c}\text { Yield } \\
\text { coefficient } \\
\mathbf{\%}\end{array}$ \\
\hline & 6 & 0.09 & 5.91 & 2.71 & 46.0 & 45.1 \\
$\mathbf{4 . 5}$ & 8 & 1.03 & 6.97 & 3.13 & 44.9 & 39.1 \\
& 10 & 1.43 & 8.57 & 3.85 & 45.0 & 38.5 \\
& 12 & 1.83 & 10.17 & 4.57 & 45.0 & 38.0 \\
& 14 & 1.92 & 12.08 & 5.31 & 43.9 & 37.9 \\
\hline & 6 & 0.04 & 5.6 & 2.80 & 46.9 & 46.6 \\
$\mathbf{5 . 0}$ & 8 & 0.08 & 7.72 & 3.75 & 47.9 & 46.2 \\
& 10 & 1.39 & 8.61 & 4.13 & 44.0 & 48.1 \\
& 12 & 0.28 & 11.72 & 5.86 & 50.0 & 48.8 \\
& 14 & 1.13 & 12.87 & 6.30 & 48.9 & 45.0 \\
\hline & 6 & 0.10 & 5.90 & 2.59 & 44.9 & 43.1 \\
$\mathbf{5 . 5}$ & 8 & 1.21 & 6.79 & 2.98 & 43.8 & 37.25 \\
& 10 & 1.47 & 8.53 & 3.83 & 44.9 & 38.3 \\
& 12 & 1.85 & 10.15 & 4.46 & 43.9 & 37.1 \\
& 14 & 2.12 & 11.80 & 5.10 & 43.9 & 36.4 \\
\hline \multirow{3}{*0.0}{} & 6 & 0.10 & 5.90 & 2.59 & 44.9 & 43.1 \\
& 8 & 1.21 & 6.79 & 2.98 & 43.8 & 37.25 \\
& 10 & 1.47 & 8.53 & 3.83 & 44.9 & 38.3 \\
& 12 & 1.85 & 10.15 & 4.46 & 43.9 & 37.1 \\
& 14 & 2.12 & 11.80 & 5.10 & 43.9 & 36.4 \\
\hline
\end{tabular}


From data in Table (7), we can observe that at $25{ }^{\circ} \mathrm{C}$ incubation temperature where the ethanol production was $6.19 \%$ with economic coefficient $46.7 \%$ when the initial sugar was $14.0 \%$. Meanwhile, the, ethanol production were $2.58,3.38,3.94$ and $5.13 \%$ when the initial sugars were 6.0, 8.0, 10.0 and 12.0\%; respectively. From the same Table (7). It is clear that incubation temperature $30^{\circ} \mathrm{C}$ was the best where the ethanol production was $6.3 \%$ with economic coefficient $49.0 \%$ when the initial sugars was $14.0 \%$. While the incubation temperature increased till $35^{\circ} \mathrm{C}$ the percentage of ethanol production decreased to $5.47 \%$ at $14.0 \%$ initial sugar this may be attributed to the ability of Saccharomy cescerevisiae to grow and active to produce ethanol under anaerobic conditions.

Table (7): Interaction between incubation temperature and initial sugars on ethanol production from molasses media using Saccharomyces Cerevisiae under optimum conditions.

\begin{tabular}{|c|c|c|c|c|c|c|}
\hline $\begin{array}{c}\text { Incubation } \\
\text { temperature } \\
{ }^{\circ} \mathrm{C} \\
\end{array}$ & $\begin{array}{c}\text { Initial } \\
\text { sugars } \\
\%\end{array}$ & $\begin{array}{c}\text { Residual } \\
\text { sugars } \\
\% \\
\end{array}$ & $\begin{array}{c}\text { Consumed } \\
\text { sugars } \\
\% \\
\end{array}$ & $\begin{array}{c}\text { Alcohol } \\
\text { production } \\
\%\end{array}$ & $\begin{array}{c}\text { Economic } \\
\text { coefficient } \\
\%\end{array}$ & $\begin{array}{c}\text { Yield } \\
\text { coefficient } \\
\%\end{array}$ \\
\hline \multirow{5}{*}{20} & 6 & 0.30 & 5.70 & 2.29 & 40.2 & 38.1 \\
\hline & 8 & 0.25 & 7.75 & 3.22 & 41.6 & 40.2 \\
\hline & 10 & 1.15 & 8.85 & 3.57 & 40.4 & 35.7 \\
\hline & 12 & 0.25 & 11.75 & 4.77 & 40.6 & 39.7 \\
\hline & 14 & 1.10 & 12.90 & 5.16 & 40.0 & 36.8 \\
\hline \multirow{5}{*}{25} & 6 & 0.35 & 5.65 & 2.58 & 45.7 & 43.0 \\
\hline & 8 & 0.30 & 7.70 & 3.38 & 44.0 & 42.2 \\
\hline & 10 & 0.97 & 9.03 & 3.94 & 43.7 & 39.4 \\
\hline & 12 & 0.32 & 11.68 & 5.13 & 44.0 & 42.7 \\
\hline & 14 & 0.37 & 13.27 & 6.19 & 46.7 & 44.2 \\
\hline \multirow{5}{*}{30} & 6 & 0.4 & 5.66 & 2.80 & 46.9 & 46.6 \\
\hline & 8 & 1.08 & 7.72 & 3.75 & 47.9 & 46.2 \\
\hline & 10 & 1.39 & 8.61 & 4.13 & 44.0 & 48.1 \\
\hline & 12 & 0.28 & 11.72 & 5.86 & 50.0 & 48.8 \\
\hline & 14 & 1.13 & 12.87 & 6.30 & 48.9 & 45.0 \\
\hline \multirow{5}{*}{35} & 6 & 0.07 & 5.93 & 2.59 & 43.8 & 43.1 \\
\hline & 8 & 0.13 & 7.87 & 3.51 & 46.6 & 43.8 \\
\hline & 10 & 0.80 & 9.20 & 4.04 & 44.0 & 40.4 \\
\hline & 12 & 0.77 & 11.23 & 4.82 & 43.0 & 40.4 \\
\hline & 14 & 0.97 & 13.03 & 5.47 & 42.0 & 39.0 \\
\hline
\end{tabular}

Conclusively, food and Agricultural wastes can be used for ethanol production using Saccharomyces cerevisiae under anaerobic condition. Maximum Yield of ethyl was $6.3 \%$ with economic coefficient $49.9 \%$ 


\section{REFERENCES}

A.O.A.C. (2005): Official Method of Analysis. Association of Official Analytical Chemists, $16^{\text {th }}$ ed., Gaithersburg, DC, USA.

Itelima, J.; Onwuliri, E. and Oforji, S. (2013). Bio-ethanol production from Banana, plantain and pineapple peels by simultaneous saccharification and fermentation process. International Journal of Environmental Science And Development. 4, (2): 213 - 216.

Kandari ,V. and Gupta, S. (2012). Bioconversion of vegetable and fruit peel wastes in viable product. Journal of Microbiology and Biotechnology Research, 2(2): 308- 312.

Nakshoo. S. A., and Ebrahim, A. (2013). Production of bioethanol using local isolate of Saccharomyces cerevis from raw sugar refining molasses. Damascus University, Journal of Agricultural Sciences,. 2(29): 261-271.

Rani, P.; Sharma, S.; Garg, F. and Wati, L. (2010).Ethanol production from potato flour by saccharomyces cerevisiae. Indian Journal Of Science And Technology, 3 (7). 733 - 736.

Singh, A. R. P. (2014). A comparative study of Bioethanol production ability of bacillus subtilis and Saccharomyces cerevisiae using banana and orange peels. International Journal Of Scientific \& Engineering Research, 5(1): 1-5.

Singh, A.; Kumar, Y.; Peter, K. and Singh, P. (2014). Bio-Ethanol production from banana peel by simultaneous saccharification and fermentation process using co cultures Aspergillus niger and Saccharomyces cerevisiae. Intr. .J. Curr. Microbio. App. Sci., 3 (5) 84 : 96.

Turhan, I., Demirci, A. and Karhan, M. (2008).Ethanol production from carob extraet by saccharomyces verevisiae. Am Soc. Agric. Engineers, $8: 17-20$. 


\section{دراسات حول امكاتيه استخدام المخلفات الزراعيه والغذائيه على انتاج كحول الايثايل}

1ـ العوامل الموثره على انتاج كحول الايثايل من مولاس بنجرالسكر

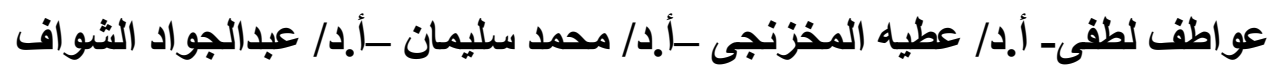

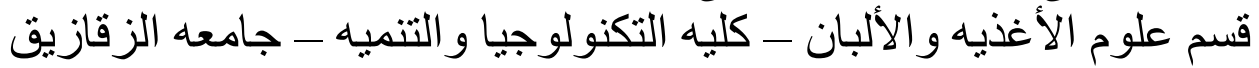

تم دراسة ظروف إنتاج الإيثانول الحيوي من مولاس بنجر السكر بواسطة

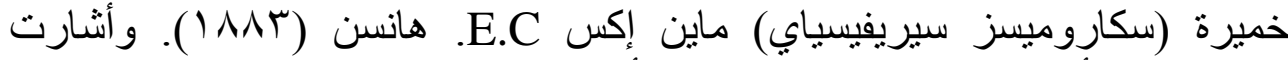

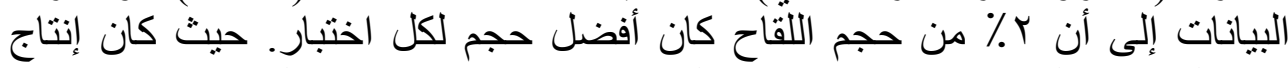

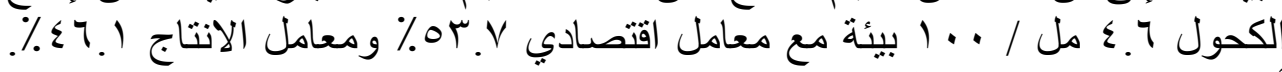

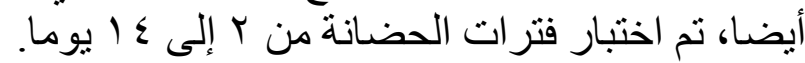

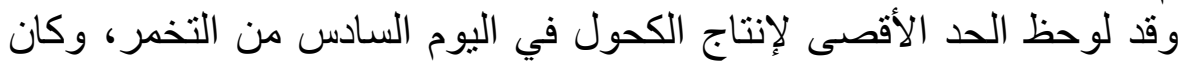

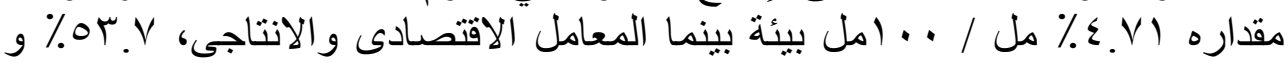

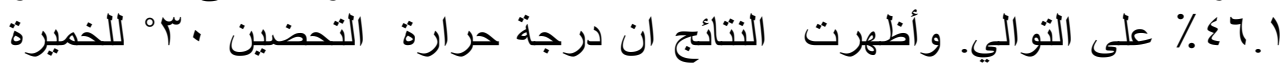

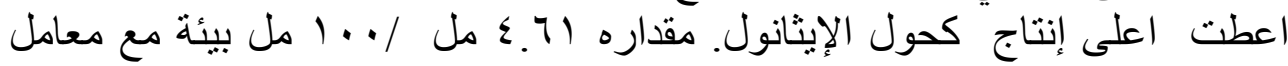

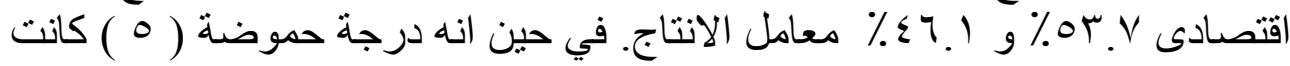

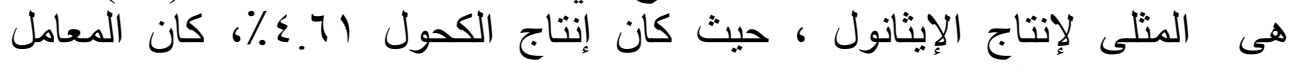

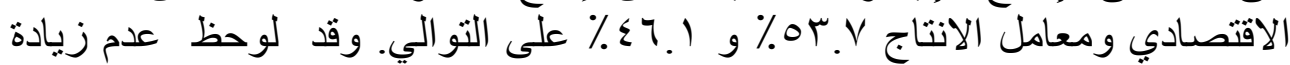

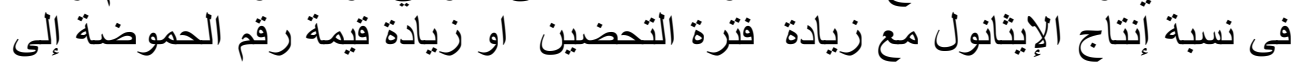

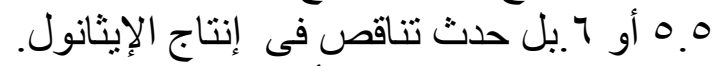

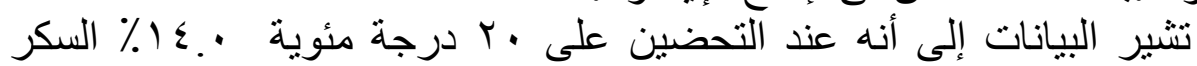

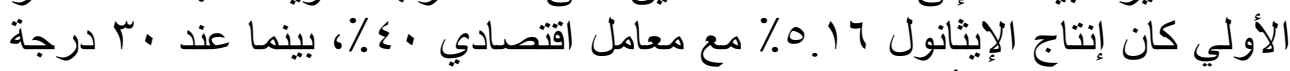

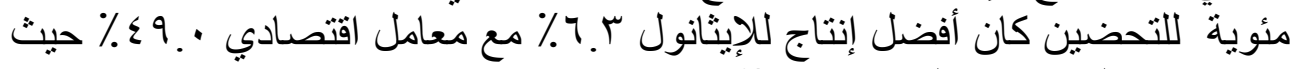

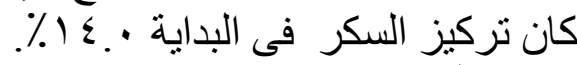

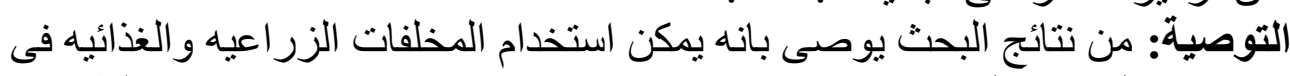

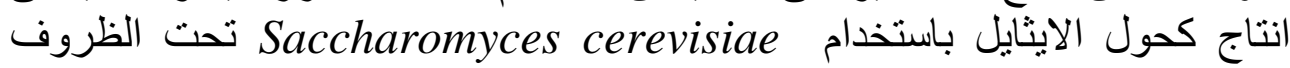

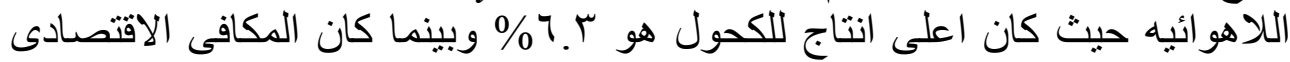
. ه ه • • 
